\title{
A Comparative Study on Conversion of Religion in Islamic Law and Malaysian Law
}

Nizaita Omar, Zulkifly Muda, Ruzaini Sulaiman @ Abdul Rahim, Istiqomah

To Link this Article: http://dx.doi.org/10.6007/IJARBSS/v10-i11/8201 DOI:10.6007/IJARBSS/v10-i11/8201

Received: 07 September 2020, Revised: 10 October 2020, Accepted: 16 November 2020

Published Online: 30 November 2020

In-Text Citation: (Omar et al., 2020)

To Cite this Article:Omar, N., Muda, Z., Rahim, R. S. @ A., \& Istiqomah. (2020). A Comparative Study on Conversion of Religion in Islamic Law and Malaysian Law. International Journal of Academic Research in Business and Social Sciences, 10(11), 1240-1247.

Copyright: (c) 2020 The Author(s)

Published by Human Resource Management Academic Research Society (www.hrmars.com)

This article is published under the Creative Commons Attribution (CC BY 4.0) license. Anyone may reproduce, distribute, translate and create derivative works of this article (for both commercial and non-commercial purposes), subject to full attribution to the original publication and authors. The full terms of this license may be seen

at: http://creativecommons.org/licences/by/4.0/legalcode

Vol. 10, No. 11, 2020, Pg. 1240 - 1247

http://hrmars.com/index.php/pages/detail/IJARBSS

JOURNAL HOMEPAGE

Full Terms \& Conditions of access and use can be found at http://hrmars.com/index.php/pages/detail/publication-ethics 


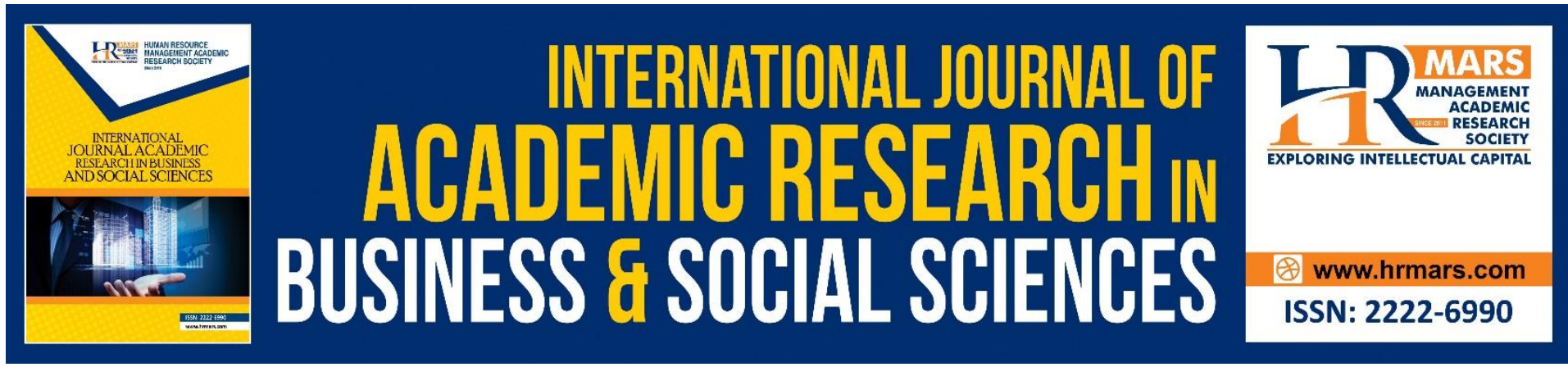

\title{
A Comparative Study on Conversion of Religion in Islamic Law and Malaysian Law
}

\author{
Nizaita Omar, Zulkifly Muda², Ruzaini Sulaiman @ \\ Abdul Rahim ${ }^{3}$, Istiqomah ${ }^{4}$
}

${ }^{1 *}$ Faculty of General Studies and Advanced Education (FUPL), Universiti Sultan, Zainal Abidin (UniSZA), Gong Badak Campus, 21300 Kuala Nerus, Kuala, Terengganu, Terengganu, Malaysia, ${ }^{2}$ Fatwa Department of Terengganu, Centre of Islamic Affairs, Kuala Terengganu, Malaysia, ${ }^{3}$ Centre for Basic and Advance Education, Universiti Malaysia Terengganu, 23000 Kuala Nerus, Terengganu, Malaysia, ${ }^{4}$ Faculty of Islamic Religion, Muhammadiyyah University Sidarjo Indonesia, Kampus 1.JI.Majapahit 666 B Sidarjo

\begin{abstract}
Islam is a pure religion. Its truth is evident. Whoever is guided by Allah to be a Muslim, he will be a Muslim and whose heart is blinded from accepting Islam as his creed, he will be a nonMuslim. As a matter of fact, the right to choose a religion or a creed is given in Islam. This is based on a general ruling in al-Quran which is "There is no compulsion in choosing a religion". However, this concept should not be seen as contrary to dakwah which must be performed by every Muslim by using wisdom, not compulsion. Islam also has laid down the guidelines and principles concerning the relationship between Muslims and non-Muslims. It is known that Islamic law was the primary law in the States of Malaya. One of the examples is the Malacca law which was applied in Malacca and had influenced other states under Malacca conquest as well. This article will analyze the subject of conversion of religion in Islamic law and in Malaysian law.
\end{abstract}

Keywords: Conversion, Religion, Islamic Law, Malaysian Law.

\section{Introduction}

Islam prohibits Muslims individually or in group from degrading the non-Muslims by insulting or humiliating their religions to prevent any hatred and chaos occurring in a society. Also, it is to protect our religion from being insulted by them. Allah said "Don't insult their idols. Otherwise, they will insult Allah and exceed in it".

Islam also teaches Muslims to protect their place of worship. Allah clearly touched on the topic of the purpose of struggle by saying "If Allah does not push people to fight against one another (in upholding their rights), temples of Christians and Jews and mosques in which the name of Allah is always remembered and mentioned will be destroyed". This is in line with the content of treaty that was agreed by Caliph Umar and the population of Quds of which the former would protect the latter's lives, properties, religions and temples under his reign (Al-Tabari, 1968). 
However, the freedom given by Islam to the non-Muslims does not mean that the status of Muslims shall be degraded by allowing negative connotations upon Islam, attending other religions' ceremonies, building their temples in districts which are inhabited by Muslims, etc. Otherwise, it would be seen as a demur and an insult to Muslims that can lead to chaos and disorder within the society (Al Qarafi, n.d).

\section{Research Objectives}

This research is meant to serve these purposes:

1. Reviewing the subject of conversion of religion in Islamic law.

2. Analyzing the issue of conversion of religion in Malaysian law.

\section{Research Methodology}

This research uses descriptive approach. Every selected issues are analyzed, explained, argued and reviewed by the researcher to obtain a verdict that is relevant and fitting with the Islamic law and capable of giving the best solution to the issues countered. The verdict, or can be termed as tarjih, takes into account the Islamic jurists' views. The analysis is used to obtain legal facts on the subject of conversion of religion in Malaysian law.

\section{Finding and Research Discussion}

We may divide it into two categories; direct conversion and indirect conversion. Direct conversion refers to conversion made by someone who is originally a non-Muslim. This kind of conversion is valid if it fulfills all requirements laid down by Islam. Indirect conversion occurs when: $i$ - someone converts to Islam then his minor child would be considered a Muslim as the child would follow his parent's religion, ii- someone minor who is discovered in a district that is inhabited by Muslims.

Following are the topics raised in this research of conversion of religion:

\section{Conditions of the Conversion}

There are a number of conditions for the conversion to be valid.

\section{First: Sound Mind}

Someone will lawfully be considered a Muslim if he converts to Islam when he is in sound mind. If someone who is mentally unsound declares his conversion to Islam, it is not considered valid. This is based on an authentic hadith (Abadi, 1979):

"Sins will be lifted from these three groups of people; minors until they attain the age of majority, the insane until they recover and the asleep until they wake up."

(Narated by Abu Dawud).

\section{Second: Baligh (Puberty)}

All Islamic jurists agreed that the conversion of a major is valid. This is because reaching the age of majority (puberty) is the main condition to taklif. However, there is a disagreement among the jurists on the issue of conversion by a minor of a sound mind.

According to Hanafi, Hambali and the second view of Shafie, this kind of conversion is valid. Their arguments are (Al Sharbini, 1958; Zaydan, 1993; al-Din, n.d): 
1. All authentic texts touching on this issue are general or vague. People of sound mind may comprise everybody with a sane mentality regardless of their status as a major or a minor.

2. It is not logically acceptable that a minor of a sound mind who embraces Islam should be rejected and his conversion should be considered as invalid due to his minority, as it will be contradictory to the principle of dakwah (inviting people to Islam).

3. It was narrated that Ali bin Abu Talib had embraced Islam when he was ten years old (still a minor).

4. Our prophet also did not reject whoever would like to say the oath of obedience (for the conversion to Islam) even though some of them were minors.

5. The hadith "...sins will be lifted from these three groups of people; minors until they attain the age of majority..." does not mean that conversion made by a minor is invalid. It only clarified on the status of taklif.

However, according to Shafie and Zufar, this kind of conversion is invalid. Their arguments are (Qalyubi, n.d; Ibn-Qudamah, 1983):

1. The hadith "... sins will be lifted from these three groups of people; minors until they attain the age of majority..." refers to the three groups of people whose taklif are lifted due to the lack in the conditions of taklif in terms of age and sanity.

2. Recitation of shahadah from a minor is considered as a statement, not a conversion.

3. They tried to contest the narration stating that Ali bin Abu Talib embraced Islam when he was a minor by bringing up another narration by Abu Talib (one of Hambali's scholars) that said Ali had already reached the age of majority when he embraced Islam. Even if the first narration was authentic, they agreed that the conversion was not considered valid until he hit puberty later.

The first view is stronger based on the arguments it presented. It is also supported by the fact that the purpose of dakwah itself is to attract people to Islam. Whatever chances we have to do so, we have to take it (Zaydan, 1993). In indirect conversion, there are two situations discussed in the book of Fiqh as below:

The first situation is when a minor whose father or mother or both embrace Islam, he is automatically considered a Muslim as he must follow the best religion embraced by one of his parents, and Islam is absolutely the best religion (al-Sharbini, 1958).

The second situation is when a laqit (minor) who is discovered in a state or area inhabited by Muslims. Conversely, he will be considered a non-Muslim if he is found in a district populated by non-Muslims except if there are also some Muslims living there. This is the view by Shafie and Hambali (al-Sharbini 1958; Ibn-Qudamah 1983). According to some jurists, the religion of the laqit accords to who discovers him (al-Kasani 1986). If he is found by a Muslim, he will be regarded as a Muslim. Otherwise, he will be considered a non-Muslim. 


\section{The Age of Puberty}

We have discussed the conversion to Islam made by minors and it is clear that some jurists put puberty as one of the requirements and conditions for a person to embrace Islam. Now we will be discussing the meaning of puberty itself.

The jurists unanimously agreed that having wet dreams (for males and females) is one of the signs of attainment of the age of puberty, and menstruation is a mark of puberty for females. If someone does not experience wet dreams or menstruation, his age of puberty will be at fifteen years old (according to the calculation of lunar calendar) (al-Qurtubi 1985; al Shawkani n.d). This view is based on a hadith that mentioned how Abdullah bin Umar tried to get a permission from the Messenger to participate in a war when he was fourteen years old. The Messenger, however, did not allow him. Then he tried again next year (when he was fifteen years old) and our Prophet gave him his permission (al-Sharbini, 1958).

Abu Hanifah was of opinion that the age of majority is eighteen years old for males and seventeen years old for females. The view is based on the fact that wet dreams usually occur around those ages (al-Shawkani, n.d).

The writer, however, is of opinion that this issue is still exposed to dispute due to the absence of firm evidence or reference. The narration about Abdullah bin Umar is not considered strong evidence although it is authentic because our Prophet probably did not refer to Abdullah's age of majority, but his ability to participate in that war itself. After being confident of his capacity and ability in the next application, our Prophet allowed him to go along with the others regardless of his status of taklif (the age of puberty).

\section{The Age of Puberty In the Perspectives of Applicable Laws}

We may divide the discussion into two categories:

i. The age of puberty in the perspective of civil law

ii. The age of puberty in the perspective of the Administration of Islamic Affairs.

According to section 12 (3) (4) of the Federal Constitution and section 4 of Age of Majority Act 1971, a person who does not reach the age of eighteen is subject to the religion of his parent or guardian even though he is considered to already reach the age of majority in Islamic law. Consequently, he cannot be considered a Muslim after converting to Islam if his parent does not approve his conversion. This is apparently in contrary with our religion which treats everybody reaching the age of majority as taklif that they must accept Islam as their religion (Zulkifly, 2000).

There is a contradiction in some states' enactment on the issue of the age of majority among people compared to the others. Some of them follow the enactment as stated in the Federal Constitution, while some others follow the Islamic law in determining the age.

As a matter of fact, the validity of conversion to Islam made by a person who has hit puberty (in the view of Islam) is not supposed to be argued. This issue, however, rises due to the question of whether or not that person should be registered as a Muslim. According to the law in our country, the conversion is invalid if his guardian does not give any approval upon his conversion. The door to get him to apostatize and return to his original religion or to 
his parent's religion is opened. If the person dies before he is considered a major, he will be buried as a non-Muslim in a non-Muslims' graveyard although he is considered a Muslim in the view of Islam (Zulkifly, 2000).

\section{Conversion to Islam According to the Malaysian Law}

Discussion of this topic could be divided into two categories of time; i) Pre-colonial era, ii) Modern era.

\section{Pre-Colonial Era}

According to the history, the Law of Malacca, or known as Hukum Kanun Melaka, was legislated by Hang Sidi Ahmad as commanded by Sultan Mansur Shah. This legislation was done based on the Islamic law, specifically in Shafie's school of thought. The customary acts of local society also affected the Malacca law as well (Bakar, 1986).

The law itself did not touch the issue of conversion to Islam because it was a primary task for everyone at that time to embrace Islam. However, it was explicitly enacted that conversion from Islam to another religion was a crime. Section 36.1 stated (Liaw, 1976):

This is the ruling of apostasy. Whoever apostatizes shall be ordered to repent to Allah three times. If he does not do so, he will not be prayed and buried in a Muslims' graveyard. Whoever leaves obligatory prayers (not due to sickness) and he denies the obligation of the prayers, he shall be ordered to repent three times and then killed if he refuses to do so.

Based on this statement, whoever apostatized must deal with:

Istitabah, meaning asking the apostate to repent to Allah within three days.

i. If he refused to do so, he should be killed.

ii. His corpse cannot be prayed and buried in a Muslims' graveyard.

Similar ruling was also applied in the Law of Pahang in section 59. Other states such as the Law of Kedah, the 99 Laws of Perak and the Old Law of Johore, however, did not enact such ruling because they were already under the Malacca conquest so they did not need any specific ruling on the issue of apostasy as they could refer to the main law (the Law of Malacca) itself (Zulkifly, 2000).

\section{Modern Era}

Malaysia as an ex British colonist still adheres to the British law introduced during the conquest of Britain. This law is actually based on written laws and unwritten laws. The former refers to the Federal Constitution as well as the Local Constitution of each state. The latter refers to decisions made by judges when handling cases. These decisions are based on the principles available in Common Law and Equity. The courts handling this decision-making process are High Courts, Federal Courts and Privy Council. The higher should bind the lower.

The unwritten laws also refer to customary laws that are adhered by local societies (Malays, Chinese, Indians and others). These laws normally involve the issue of marital system, divorce, inheritance, land possession and special customary acts (Wu, 1990). 
According to the ruling mentioned earlier, whoever does not reach the age of eighteen, his right to choose a religion is subject to his guardian's judgment although he has already attained the age of puberty in the perspective of Islam. This makes this ruling contradictory to the Islamic law.

However, different enactments are set by each state's authority regarding this issue. Some of them follow what is in the Federal Law, while some others choose to refer to the Islamic law and make it as a tenet or a benchmark on this issue.

There is a conflict in terms of the status of minor converts who have hit puberty but are not considered Muslims by the civil law. Their religions are subject to the judgment of their guardians which could result in them being conveyed back to their original religions or religions that are approved by their guardians. Consequently, they might apostatize. Certainly, this is contrary with the Islamic law. This could also imply that these minors will be buried in non-Muslims' graveyards if they die before reaching the age of eighteen just because they had no right to register themselves as Muslims without the consent from their guardians (Wu, 1990).

The enactment in Pahang Administration of Islam 1982 (section 101) is apparently similar to what has been enacted in the Federal Law. Hence, there is no compliance with the Islamic law that opens the door widely to whoever would like to embrace Islam after they have hit puberty. Even though the Hanafi's school of thought set the age of eighteen as the age of puberty but it established a ruling that despite still being a minor, if someone already possesses a sound and rational mind, his conversion is considered valid. We have previously discussed this issue in the beginning of this paper (Zulkifly, 2000).

According to section 3 of the Law of Muallaf Registration 1967, a muallaf (a person who newly embraces Islam) should be made sure that he has already reached the age of eighteen (like what is enacted in the Federal Constitution s. 12 sub. 4) before being accepted and registered as a Muslim. This enactment is certainly contradictory with the Islamic law (Zulkifly, 2000).

\section{Conclusion}

Islam absolutely forbids its people from disturbing others' religions or creeds. NonMuslims' freedom to practice their religions is guaranteed and preserved in Islamic law. If this right is not recognized, that means there is no contract of zimmah (treaty between Islamic authority and the non-Muslims). It was narrated that the Messenger of Allah in one of his own letters sent to the society of Najran (Christian people) had mentioned that they and also other societies around them were in peace with Allah and His Messenger that their properties, religions, temples and possessions would be protected.

\section{Acknowledgement}

Highest appreciation is intended to Universiti Sultan Zainal Abidin for the sponsor and support provided in making this research possible. 


\section{Corresponding Author}

Nizaita Omar

Faculty of General Studies and Advanced Education (FUPL)

Universiti Sultan Zainal Abidin (UniSZA), Gong Badak Campus, 21300 Kuala Nerus, Kuala Terengganu, Terengganu,Malaysia.

Email: nizaitaomar@unisza.edu.my

\section{References}

Al Quran.

Al Qarafi, S. A. (n.d). al Furuq. Beirut: Alam al Kutub

Abadi, A. A. (1979). 'Aun al Ma'bud Syarh Sunan Abi Dawud. Beirut: Dar al Fikr

Al Sharbini. (1958). Mughni al Muhtaj. Cairo: Matba'ah Mustafa al Halabi

Zaydan. (1993). al Mufassal fi Ahkam al Mar'ah wa al Bait al Muslim. Beirut: Muassasah al Risalah

Zulkifly, M. (2000). Pertukaran Agama dan Mazhab; Implikasinya Terhadap Undang-Undang Diri di Malaysia. Bangi: Universiti Kebangsaan Malaysia

Al Tabari, J. M. (1968). Tarikh al-Rusul wa al-Muluk, Cairo: Dar al-Ma'arif

Ibn Qudamah, M. A. (1983). al Mughni. Beirut: Dar al Kitab al 'Arabi

Al-Qalyubiyy. (n.d). Qalyubiyy wa 'Umayrah, Cairo: Dar Ihya al-Kutub al-'Arabiyyah

Al-Kasani. (1986). Badai' al-Sanai' fi Tartib al-Sharai'. Beirut: Dar al-Kutub al-'Ilmiyyah

Al-Qurtubi, A. (1985). Al Jami' al Ahkam al Quran, Beirut: Dar Ihya al-Turath al-'Arabiyy, Beirut Al Shawkani, 'A. M. (n.d). Fath al-Qadir. Beirut: 'Alam al-Kutub, Beirut

Abdullah, A. B. (1986). Ke Arah Perlaksanaan Undang-undang Islam di Malaysia: Masalah dan Penyelesaiannya. Kuala Terengganu: Pustaka Damai

Fang, L. H. (1976). Undang-Undang Melaka. The Hague: Maritimes Nijhot

Aun, W. M. (1990). The Malaysian Legal System. Petaling Jaya: Longman Malaysia Sdn. Bhd 